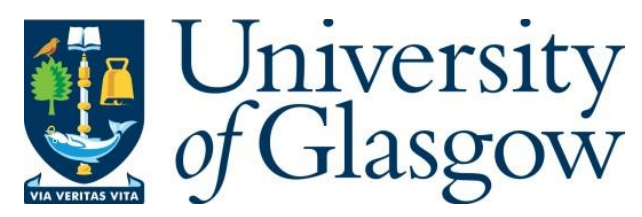

Brophy, K. (2018) The Brexit hypothesis and prehistory. Antiquity, 92(366), pp. 16501658.

There may be differences between this version and the published version. You are advised to consult the publisher's version if you wish to cite from it.

http://eprints.gla.ac.uk/170527/

Deposited on: 23 October 2018

Enlighten - Research publications by members of the University of Glasgow

http://eprints.gla.ac.uk 


\section{The Brexit hypothesis and prehistory}

Kenneth Brophy*

*Archaeology, School of Humanities, University of Glasgow, Glasgow G12 8QQ, Scotland, UK (Email: kenny.brophy@glasgow.ac.uk)

Received: 22 February 2018; Revised: 30 July 2018; Accepted: 7 August 2018

Archaeologists have more opportunities than ever to disseminate their research widely - and the public more opportunities to engage and respond. This has led to the increasing mobilisation of archaeological data and interpretations within the discourses of nationalism and identity politics. This debate piece introduces the Brexit hypothesis, the proposition that any archaeological discovery in Europe can — and probably will-be exploited to argue in support of, or against, Brexit. Examples demonstrate how archaeological and ancient DNA studies are appropriated for political ends and a series of recommendations and strategies for combatting such exploitation are proposed by the author.

Keywords: Europe, Britain, prehistory, Brexit, nationalism, aDNA

\section{The Brexit hypothesis}

Today, archaeologists work in an environment where the results of our research projects are scrutinised by the public for the potential to inform, evidence and reinforce differing positions on major socio-economic and political issues. Once published, archaeological data and conclusions are used in ways that we neither intended, nor fully understand. While it is undoubtedly positive that the visibility of, and access to, such research is growing, a dark side to this phenomenon is becoming increasingly evident. Here, I argue that archaeologists must think more deeply about how our research will be reported and consumed by (social) media and the public, and also be ready and willing to enter debate and push back against problematic appropriations of archaeological research.

Archaeologists now have more outlets and opportunities to communicate research outcomes than at any other time in the history of our discipline. The means of reaching large audiences — albeit with limited potential to identify specific impact—include mass media outlets (analogue and digital) and online routes for dissemination (notably social media). In turn, our results, which sometimes involve complex scientific methods, have increased 
visibility within public discourse. While there is much to be positive about, it should be tempered with caution; such visibility comes with the expectation that, potentially, everyone can, and often does, have an opinion. This is not the comfortable, rule-bound world of peer review.

This debate piece considers these issues by introducing the Brexit hypothesis, the proposition that any archaeological discovery in Europe can — and probably will— be exploited to argue in support of, or against, Brexit (the ongoing political process by which the UK leaves the European Union, following the June 2016 referendum). Brexit is tied up with a range of urgent social issues, including immigration, identity politics and self-determination, with implications for hundreds of millions of people across Europe. Archaeological research projects and results - even those related to prehistory - have become entangled in major Brexit-related socio-political discussions. For a flavour of how this Brexit neurosis plays out, simply enter the world of newspaper commentary, social media timelines, below-the-line comments associated with online articles and politically motivated websites. This is a much broader problem than Brexit and prehistoric archaeology, but the Brexit hypothesis offers a timely case study. The issues, concerns and solutions suggested here should be viewed as more widely applicable.

\section{Brexit neurosis}

The study of prehistory has never been apolitical. The current politically situated interpretation of prehistory in the court of public opinion revives memories of the 'invasion neurosis' skewered by Grahame Clark (1966) in the pages of this journal. Clark identified trends and fashions within British prehistoric archaeology influenced by contemporaneous ideas of national identity, the history of Britain as subject to a series of invasions and decline of the Empire. There was a certain self-deprecating, reserved 'Britishness' about how prehistory was studied, Clark argued: the druid a figure of fun; "every change, every development" explained by "overseas influences of one kind or another" (Clark 1966: 172). The historical structure of the UK and its relations with Ireland have more recently been identified as influencing the way that Neolithic studies developed in Britain (Barclay 2001); these could be interpreted as an indication of historical, unconscious bias towards ideas derived from English archaeological sites and materials. The explicit use and abuse of prehistory for political ends in the twentieth century includes the 'Ulster exceptionalism' of archaeologist Emyr Estyn Evans - an attempt to demonstrate variability in the distribution of 
megalithic tombs across Ireland, with obvious political motivations (Stout 1996). At the most extreme end of the scale were the actions of Nazi archaeologists (Arnold 2006).

Clark's (1966: 173) warning of “obsessive and dangerous” readings of prehistory is more apposite than ever. Yet archaeologists are only now starting to investigate ways in which their research is being used by the public and interest groups across popular culture and traditional and social media to draw parallels, support arguments and define personal and national identities. Worrying trends are emerging, as identified by the mining of 'big data' associated with online debate. Bonacchi et al. (2018), for example, have analysed 1.4 million posts, comments and replies on 364 Facebook sites related to Brexit, and found a profusion of spurious historical parallels between the Roman Empire and the EU. Their research discovered that

the past was leveraged in relation to certain issues more than others, and especially to the movement of people, their subsequent interactions and the threats and opportunities caused by these dynamics in terms of identity and law and order (Bonacchi et al. 2018: 181).

Similar concerns with utilising the ancient past to justify opinions on contemporary issues such as immigration, race and identity, political self-determination, national identity and borders are evident in online discussion fora and social media associated with the alt-right (Richardson \& Booth 2017). In other words, the evoking of events from thousands of years ago as relevant to contemporary political discourse is not a problem consigned to the Clarkian past - it remains deeply problematic.

Brexit represents a modern example and is quickly becoming our 'neurosis'. Prehistoric research projects in the UK are now routinely discussed by journalists using Brexit terminology. Media coverage of a project on sea-level changes in the North Sea and English Channel, for example, characterised rising sea levels in the Mesolithic as the cause of 'the first Brexit' (Campbell 2017). Media spin of ancient DNA (aDNA) results associated with Beaker-using people in North-west Europe (Olalde et al. 2018) conjured up a declining, isolationist British 'Neolithic Brexit' (Rincon 2018). Brexit has become a convenient but deeply problematic metaphor that conditions readers to react to these reports in certain ways. This is not restricted to prehistory; there is extensive evidence in the 'Brexit Facebooksphere' for invoking issues related to the Romans (such as the use of words 'Roman' and 'Britannia') by those taking pro- and anti-Brexit stances (Bonacchi et al. 2018: 181-82). Brexit is therefore not only a real and present danger for the archaeological profession in the UK (Gardner 2017; Gardner \& Harrison 2017: 2); there is also a danger that Brexit and associated 
concerns will dominate how the results of our archaeological projects are consumed by the public.

\section{Mobility, identity, nationalism and television prehistory}

In 2017, the BBC aired two television documentary series, based on new archaeological research, each perceived by some viewers to make allusions to modern political concerns. For some viewers, narratives about Neolithic lives in Britain affirmed their existing political and personal beliefs, while for others these programmes were indicative of state-broadcaster propaganda. The first was a three-part documentary, Britain's ancient capital: secrets of Orkney (BBC2, January 2017); the second was Invasion! with Sam Willis (BBC4, December 2017). Britain's ancient capital promoted the hypothesis that Orkney was a centre of Neolithic innovation, with material culture, monuments and house styles 'invented' in this northern archipelago spreading across Britain during the third millennium BC, culminating in the final phases of Stonehenge. Invasion! explored the apparent succession of invasions and mass migrations affecting Britain since the end of the last Ice Age. Drawing heavily on aDNA evidence, major cultural, social and ideological change was attributed to immigrants. Both series were entertaining, and drew strong viewing figures. Both also conform to the Brexit hypothesis, as they were interpreted by some viewers through the lens of Brexitwhether with regard to how different parts of the UK relate to each other or to the relationship between Britain and continental Europe.

Britain's ancient capital attracted over 3 million viewers (B.A.R.B. 2018), and demonstrated how politically entangled television prehistory can become. The core focus of the series on Orkney as Britain's 'ancient capital'—a nonsensical notion (Brophy 2017)—exposed the show to the critique of being politically motivated. The lead presenter, archaeologist and historian Neil Oliver, is widely known to be an opponent of Scottish independence. For some viewers, this coloured their interpretation of the programme. This was reflected in tweets such as one suggesting that the programme was "BBC state sponsored support for the Union" (Kev R @ kwr66: https://twitter.com/kwr66/status/824580783272787968). The failure of presenters to mention the word 'Scotland' in any episodes, and repeated reinforcement of Orcadian connections with Britain and Stonehenge was, according to some on social media, a subtle way for the producers to suggest that Scotland had always been part of Britain. One viewer, for example, tweeted "constant mentions of a United Brit culture!" (@Rog_Anderson: https://twitter.com/Rog_Anderson/status/899370747197620228).Such interpretations, which diminish the significance of Orkney's Neolithic archaeology, could 
have been pre-empted. Instead, nationalist agendas and political narratives were emboldened by the failure of the producers and presenters to articulate clearly that prehistoric and modern political boundaries and claims of power have nothing whatsoever in common.

Invasion! is more explicitly politically situated. Prehistoric narratives were underpinned by retro-diffusionary arguments, the repeated claim that change and innovation in Britain has always depended on fresh invasions of immigrants from continental Europe (the presenter suggested an "invasion of [...] farmers" in "relentless waves"). Archaeological evidence for the origins of farming and the uptake of Beaker-associated cultural traits were downplayed at the expense of the uncritical use of aDNA evidence. Inevitably, much of the media and public response to this programme was driven by Brexit neurosis; newspaper reviews and social media responses demonstrate that the programme was being politicised even as it was broadcast, with recurrent themes of immigration and British national identity. The politically central Independent newspaper stated that: “At first glance, Invasion! with Sam Willis was just another skirmish in what its enemies regard as the BBC's unremitting guerrilla war against Brexit" (O'Grady 2017). The review, however, also goes on to align the show's depiction of Boudica with the politics of the right-wing United Kingdom Independence Party (O'Grady 2017). The right-wing Daily Express review was more forceful:

There's no real reason why Britain, or the place we call Britain now, should be more invaded or more made up of immigrants than any other place.

There's also no real reason why Dr Sam had to keep on banging on about it unless perhaps he, or the BBC, thought we were all daft racists (Baylis 2017).

Both programmes demonstrate how the Brexit hypothesis works: fresh research and ideas are presented in a manner that invites viewers to draw inappropriate parallels between the UK and Europe in prehistory and today, and engagement with the archaeology itself is minimised. The lessons to be learned? Problems emerge when we reheat old ideas, simplify arguments, produce clickbait headlines and fail adequately to predict and pre-empt how all of this will be consumed.

\section{Ancient DNA, Britons and news media prehistory}

The scientific evidence used in Invasion! gave credibility to the arguments presented. In the so-called 'CSI-effect', the public are accustomed to DNA being used in a court of law as infallible evidence, and perceptions of the efficacy and reliability of DNA have been reinforced in media depictions (Brewer \& Ley 2010). Media reporting of prehistoric aDNA evidence is rarely accompanied by caveats concerning the problematic nature of interpreting 
such results (see, for example, Hoffman 2015), or how these data differ from public preconceptions about DNA. Thus, there is huge potential for confusion between ancestry, ethnicity and identity in the reception of media reports about aDNA studies relating to, most commonly, archaeological mobility and social change. This is confirmed by Richardson and Booth's (2017) research into online alt-right responses to aDNA stories, which reveals frequent politicised interpretations of archaeological genetics data. Troubling instances have been identified of "popular and academic articles in the public domain [...] being misinterpreted, misused and used to uphold ultra-racist political beliefs within complex social contexts online" (Richardson \& Booth 2017: 2). Yet one does not have to enter alt-right discussion fora and far-right websites to find comments of an offensive—or simply confused-nature in relation to such research. In line with the Brexit hypothesis, for instance, a trend has emerged in the UK in which the reporting of aDNA projects commonly uses the inappropriate term 'Briton', thus confusing genetic results with historical national identity, and entangling those research projects in a Brexit discourse.

This trend was evident in early 2018 in the extensive press coverage of a project studying 'Cheddar Man', a Mesolithic burial discovered in 1903 in Gough's Cave, Somerset, England. Researchers sequenced the DNA of this prehistoric individual and created a facial reconstruction; the most significant results were that Cheddar Man probably had dark skin and blue eyes (see Lotzof 2018). Widespread online and newspaper coverage and lively social media discussion (\#CheddarMan) demonstrated how universally media and public responses to this story were viewed through the prisms of immigration, British identity, race and Brexit. Media headlines repeatedly called Cheddar Man the 'first Brit' or 'first Briton' (both nonsensical and inaccurate terms), although to what extent the research team encouraged this is unclear (Lotzof 2018).

The Cheddar Man story is remarkable because of the excessive (social) media coverage and below-the-line comments focused on his appearance. For some, the story was interpreted as an anti-racism feel-good story and riposte to Brexit-related anti-immigrant arguments. The Guardian 'pick' of comments responding to the story was: "We all came from Africa and arrived here at different times. Once we realise this then maybe we could try being nice to each other" (comment by Finbaar, after Devlin 2018). For other people, however, this was a clear example of left-wing, academic, anti-Brexit, politically correct propaganda —an example of fake news, an accusation also made in social media and newspapers about, for example, Invasion. Comments on the initial story in the Brexit-supporting Daily Mail (Fernandez et al. 2018) ranged from: “They talk as if 10000 years is 10 minutes, I don't care 
who we evolved from, it's our island and you're not having it" (Jiminy-Billybob: http://www.dailymail.co.uk/reader-comments/p/comment/link/281066355)

to "This is the usual claptrap to try and make us ashamed of being white" (Tom Moncrieffe: http://www.dailymail.co.uk/reader-comments/p/comment/link/281074955)

. The ongoing response to this man's skin colour can be sampled by searching online for the term 'Cheddar Man debunked'. This reveals multiple voices disputing claims made by the research team, and revisionism and scepticism of expertise that conforms to the 'post-truth' environment of the Brexit hypothesis.

Attempts were made to pre-empt such interpretations, with team member Tom Booth informing The Guardian that "[Our research] really shows that these imaginary racial categories that we have are really very modern constructions [...] that really are not applicable to the past at all" (Devlin 2018). Booth also responded to political interpretations of the story in broadcast interviews and on Twitter. By pushing back against inappropriate interpretations of research, archaeologists can subvert the Brexit hypothesis - although this had limited success in the case of Cheddar Man. High-profile Classics professor, Mary Beard, has also attempted to push back — at personal cost. A BBC school video depicting a black Roman soldier and his family living in Roman Britain caused controversy in the alt-right community. Beard commented on Twitter that the video was in keeping with our understanding of cultural diversity in Roman Britain. There followed, via social media, "a torrent of aggressive insults, on everything from my historical competence and elitist ivory tower viewpoint to my age, shape and gender" (Beard 2017). Clearly, pushing back is not an easy course to take.

This hostile atmosphere may be one reason why aDNA studies are commonly used in the public domain to underpin arguments about the positives and negatives of immigration with little or no intervention from archaeologists or geneticists. In the same month as the Cheddar Man story, UK media coverage of a project exploring genomic data from North-west European Beaker-related burials (Olalde et al. 2018) fixated on the fate of 'ancient Britons' (i.e. indigenous Neolithic farmers), and how this resonated in Brexit Britain. The Daily Mail stated that: "the builders of Stonehenge [...] were almost completely wiped out by mysterious Beaker people whose blood runs in Brit veins to this day" (Borkhataria \& Allen 2018). Reader discussion beneath the story included racist and politically motivated comments (such as “Today you can replace the word 'Beaker' with 'Muslim” (Friction Lights: www.dailymail.co.uk/sciencetech/article-5413607/Neolithic-farmers-wiped-Beakerpeople.html)), underscoring the urgency with which archaeologists must respond, in a more 
forceful and proactive manner than is currently the case; it is, after all, our research that is providing fuel for these discussions.

\section{Combating the Brexit neurosis}

How might archaeologists combat the consequences of the Brexit hypothesis and similar challenges elsewhere? For example, the reception of DNA analysis of human remains in Africa has the potential for the sinister exploitation of results (Prendergast \& Sawchuk 2018: 812). Archaeological research has the potential to be exploited by interest-groups in matters such as the rights of indigenous peoples and first settlers, refugee situations, conflicts, claims to territory, border controls and the construction of walls. Our response to this cannot simply be to shrug our shoulders and retreat back to our ivory towers.

Firstly, further research is required to understand how individuals and interest groups consume and use archaeological research. 'Big data' analysis of social media and online discussion is an emerging research area, but important work to date has necessarily had a relatively narrow focus (e.g. Richardson \& Booth 2017), and "internet-pervaded and networked society remain largely unexplored" (Bonacchi et al. 2018: 175). Such research should further illuminate deeply problematic interpretations of prehistory. Social media mining needs to become an essential archaeological digital fieldwork technique because, as Richardson (2013: 8) has argued, "we need to base our understanding of how the public uses archaeology on the Internet on more than improvisation and chance". Crucially, such analysis must lead to action. It should help to inform future research projects by raising awareness of potential problems in how results might be perceived and exploited by the media and the public. A consideration of these issues should be undertaken at the project design stage and factored into impact strategies. Funders might also request 'plain language' explanations of projects to include politically aware commentary and 'trigger warnings'.

The dissemination of the results of archaeological projects also requires more care and thought. Social media should be used responsibly and with thoughtfulness, and press releases crafted to avoid clickbait headlines and hostages to fortune. For those of us approaching the media with our research, we should have prior discussion with institutional media teams. There should be an awareness of the potential for research results to be appropriated into major socio-political arguments. While there is no reason why archaeologists cannot contribute to debates on mass migration, conflict, political instability, identity politics and climate change, this should be done with caution and clarity: "we must all strive for public debates to remain rooted in truth" (Prendergast \& Sawchuk 2018: 812). Archaeologists 
involved in advising the producers of television programmes and media campaigns should consider potential pitfalls in how that information might be presented and consumed, and counsel accordingly and stay strong under pressure. In such politically and socially complex and fraught times, our position should not be undermined, nor debate-fuelled, by reheating old-fashioned ideas, using anachronistic or ambiguous terminology, presenting complex results uncritically or chasing easy headlines.

Finally, as archaeologists, we all have a responsibility to be vigilant and should be prepared to enter the public arena to correct mistakes, such as asking journalists to use 'people', and not 'man', in their headlines, but also to be prepared to push back against erroneous and inappropriate uses of the past for political ends. We need more prehistorians and historical archaeologists to become engaged public intellectuals like Mary Beard, although to do so undoubtedly requires forethought, vigilance, time, rigour and, in some cases, courage. Military archaeologist Gordon Barclay, for example, regularly engages with those on social media who misrepresent his research for their own political ends, and has extensively researched the historiography and origins of these and other misrepresentations of the past (Barclay 2017). Archaeologists must be willing to engage with, and call out, egregious and fallacious arguments that draw on prehistoric and aDNA evidence wherever they are found, face up to trolls, go beneath the line and engage in the comments field, and be visible social media commentators. This is our responsibility, and it needs to be a commitment for the long term because every generation gets the Brexit hypothesis that it deserves.

\section{Acknowledgements}

I would like to thank Chris Scarre for inviting me to write this piece. Gordon Barclay, Michael Given and Helen Green looked over draft versions of this paper, and their comments were very much appreciated, while the final version benefited greatly from insightful comments from anonymous referees.

\section{References}

ARNOLD, N. 2006. 'Arierdämmerung': race and archaeology in Nazi Germany. World Archaeology 38: 8-31. https://doi.org/10.1080/00438240500509744

B.A.R.B. 2018. Viewing data: all the latest reports. Available at: www.barb.co.uk/viewingdata/ (accessed 28 August 2018). 
BARCLAY, G.J. 2001. 'Metropolitan' and 'parochial'/'core' and 'periphery': a historiography of the prehistory of Scotland. Proceedings of the Prehistoric Society 67: 1-18. https://doi.org/10.1017/S0079497X00001596 - 2017. The birth and development of a factoid 2013-17: the invention of history in the Scottish independence debate. Darrow. Available at: http://darrow.org.uk/wordpress/wpcontent/uploads/2017/11/Factoid_2017_V_2.3.pdf (accessed 28 August 2018).

BAYLIS, M. 2017. Invasion! with Sam Willis: a good series but for the shrill voice and the crude arguments. Daily Express, 6 December 2017. Available at: www.express.co.uk/showbiz/tv-radio/888754/Invasion-with-Sam-Willis-TV-review-Kirsties-Handmade-Christmas-channel-four (accessed 28 August 2018).

BEARD, M. 2017. Roman Britain in black and white. Times Literary Supplement August 2017. Available at: www.the-tls.co.uk/roman-britain-black-white/ (accessed 28 August 2018).

Bonacchi, C., M. AltaweEl \& M. KrZYZAnsKa. 2018. The heritage of Brexit: roles of the past in the construction of political identities through social media. Journal of Social Archaeology 18: 174-92. https://doi.org/10.1177/1469605318759713

BorkHATARIA, C. \& V. Allen. 2018. How the builders of Stonehenge ... were almost completely wiped out by mysterious Beaker people whose blood runs in Brit veins to this day. Daily Mail, 22 February 2018. Available at: http://www.dailymail.co.uk/sciencetech/article-5413607/Neolithic-farmers-wiped-Beakerpeople.html (accessed 28 August 2018).

BREWER, P.R. \& B.L. LEY. 2010. Media use and public perceptions of DNA evidence. Science Communication 32: 93-117. https://doi.org/10.1177/1075547009340343

BROPHY, K. 2017. Celebrate Neolithic Orkney_but leave out Stonehenge. Island Review. Available at: http://theislandreview.com/content/bbc-neolithic-orkney-neil-oliver-kennethbrophy-archaeology-stonehenge (accessed 28 August 2018).

CAmpbell, A. 2017. The first Brexit: submerged landscapes of the North Sea and Channel. The Guardian, 26 April 2017. Available at: https://www.theguardian.com/science/2017/apr/26/the-first-brexit-submerged-landscapes-ofthe-north-sea-and-channel (accessed 28 August 2018).

Clark, G. 1966. The invasion hypothesis in British prehistory. Antiquity 40: 172-89. https://doi.org/10.1017/S0003598X00032488 DEVLIN, H. 2018. First modern Britons had 'dark to black skin', Cheddar Man DNA analysis reveals. The Guardian, 7 February 2018. Available at: 
https://www.theguardian.com/science/2018/feb/07/first-modern-britons-dark-black-skincheddar-man-dna-analysis-reveals (accessed 28 August 2018).

Fernandez, C., H. PetTit \& T. Collins. 2018. Face of the first Briton is revealed: DNA analysis shows 10,000-year-old man had 'dark to black' skin with BLUE eyes and curly hairand he shares up to 10\% of his DNA with today's Brits. Daily Mail online, 7 February 2018. Available at: http://www.dailymail.co.uk/sciencetech/article-5358699/First-Brit-darkskinned-blue-eyed.html (accessed 28 August 2018).

GARDNER, A. 2017. Brexit, boundaries and imperial identities: a comparative view. Journal of Social Archaeology 17: 3-26. https://doi.org/10.1177/1469605316686875

GARDNER, A. \& R. HARRISON. 2017. Brexit, archaeology and heritage: reflections and agendas. Papers from the Institute of Archaeology 27: article 24, 1-6.

HoFFMAN, D. 2015. What have genetics ever done for us? The implications of aDNA data for interpreting identity in Early Neolithic Central Europe. European Journal of Archaeology 18: 454-76. https://doi.org/10.1179/1461957114Y.0000000083

Lotzof, K. 2018. Cheddar Man: Mesolithic Britain's blue-eyed boy. National History Museum website. Available at: http://www.nhm.ac.uk/discover/cheddar-man-mesolithicbritain-blue-eyed-boy.html (accessed 28 August 2018).

O'GRADY, S. 2017. TV Review. Invasion! with Sam Willis (BBC4). Who do you think we are? You might be surprised! Independent, 26 December 2017. Available at: www.independent.co.uk/arts-entertainment/tv/tv-review-invasion-with-sam-willis-bbc4motherland-bbc2-a8087676.html (accessed 28 August 2018).

OlALDE, I. et al. 2018. The Beaker phenomenon and the genomic transformation of northwest Europe. Nature 555: 190-96. https://doi.org/10.1038/nature25738 Prendergast, M.E. \& E. SAWChUK. 2018. Boots on the ground in Africa's DNA 'revolution': archaeological perspectives on ethics and best practices. Antiquity 92: 803-15. https://doi.org/10.15184/aqy.2018.70

RiCHARDSON, L. 2013. A digital public archaeology? Papers from the Institute of Archaeology 23: article 10, 1-12.

RICHARDSON, L. \& T. BoOTH. 2017. Response to 'Brexit, archaeology and heritage: reflections and agendas'. Papers from the Institute of Archaeology 27: article 25, 1-5. RinCON, P. 2018. Ancient 'Britons' replaced by newcomers. Available at: www.bbc.co.uk/news/science-environment-43115485 (accessed 28 August 2018). 
STOUT, M. 1996. Emyr Estyn Evans and Northern Ireland: the archaeology and geography of a new state, in J.A. Atkinson, I. Banks \& G. O’Sullivan (ed.) Nationalism and archaeology: 111-27. Glasgow: Cruithne. 